\title{
2D electrical resistivity tomographies for investigating recent activation landslides in Basilicata Region (Southern Italy)
}

\author{
Gerardo Colangelo $\left({ }^{1}\right)$, Vincenzo Lapenna $\left({ }^{2}\right)$, Antonio Loperte $\left({ }^{2}\right)$, \\ Angela Perrone $\left(^{2}\right)$ and Luciano Telesca $\left({ }^{2}\right)$ \\ ${ }^{1}$ ) Dipartimento Infrastrutture e Mobilità, Regione Basilicata, Potenza, Italy \\ $\left.{ }^{(}\right)$Istituto di Metodologie per l'Analisi Ambientale (IMAA, CNR), Tito Scalo (PZ), Italy
}

\begin{abstract}
The results of a geoelectrical survey in the study of recent activation landslides in the Lucanian Apennine chain (Southern Italy) are discussed in this paper. During the last two years, after meteorological conditions which affected Southern Italy and in particular Basilicata Region, many landslides occurred in this area as reactivations of old movements. These reactivations seriously damaged buildings and infrastructure and they threatened the safety of the people living in the area. Taking into account the complexity and danger of the phenomena, some evacuation decrees for a few houses were adopted. In a short time and at low cost, by using the Mobile Laboratory of IMAA for geophysical measurements, active geoelectrical investigations were carried out and data processing performed using innovative techniques for data inversion. The results represent a valid cognitive support to choose the most appropriate technical solution for strengthening of the slopes and an example of best practice for the cooperation between the Civil Protection of Basilicata Region and IMAA-CNR.
\end{abstract}

Key words landslides - electrical resistivity tomography

\section{Introduction}

Precipitation in Southern Italy during the 2005 winter was heavier than the norm. In particular, the months of December and February were characterized by an anomaly of about $50 \%$ more than the normal values (fig. 1).

The Basilicata Region (Southern Italy) particularly suffered from this meteorological situation. Many snowy events also occurred in the

Mailing address: Dr. G. Colangelo, Dipartimento Infrastrutture e Mobilità, Regione Basilicata, C.so Garibaldi, 85100 Potenza; e-mail: gerardo.colangelo@regione.basilicata.it region between November 2005 and March 2006 with snow blanket changing in the range 0.30-1.00 m (www.sinanet.apat.it, 2005). These climatic conditions worsened the physical and mechanical characteristics of the terrains outcropping in the region. In particular, the intense precipitations increased their saturation degree and the pore pressures. The snow blanket made the slope heavy and changed the equilibrium of the strengths involved in its stability. Therefore, many dormant landslides, which affected the lucanian slopes in the past were reactivated. The main typologies of reactivation have been earth-flow, translational or rotational slides. The new slides involved buildings and infrastructures constructed on the slopes. The risk for people and assets needed the intervention of the end users involved in risk management and, in particular, the inspection of the Regional Department of Infrastructure and Civil Protection (RDICP). In many involved areas and for many 


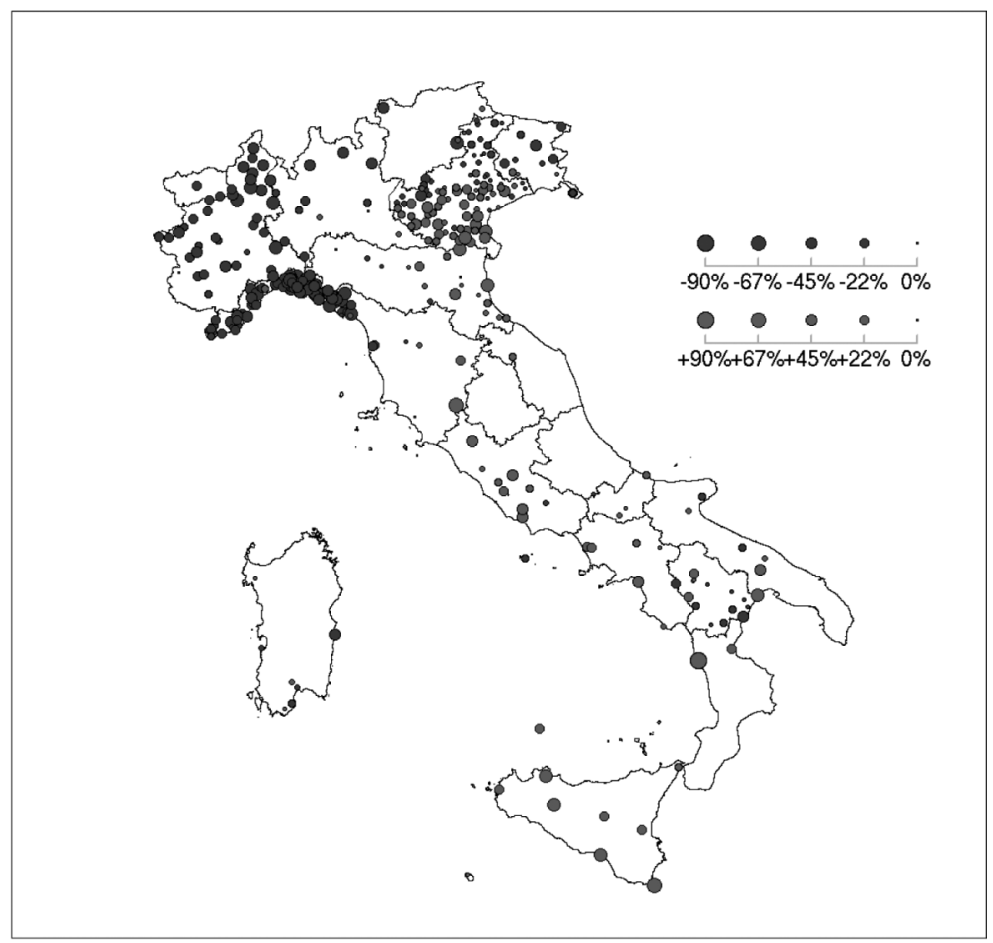

Fig. 1. Anomalies of accumulated precipitation 2005 (in percentage values) respect to the normal values 19611990 (from www.sinanet.apat.it).

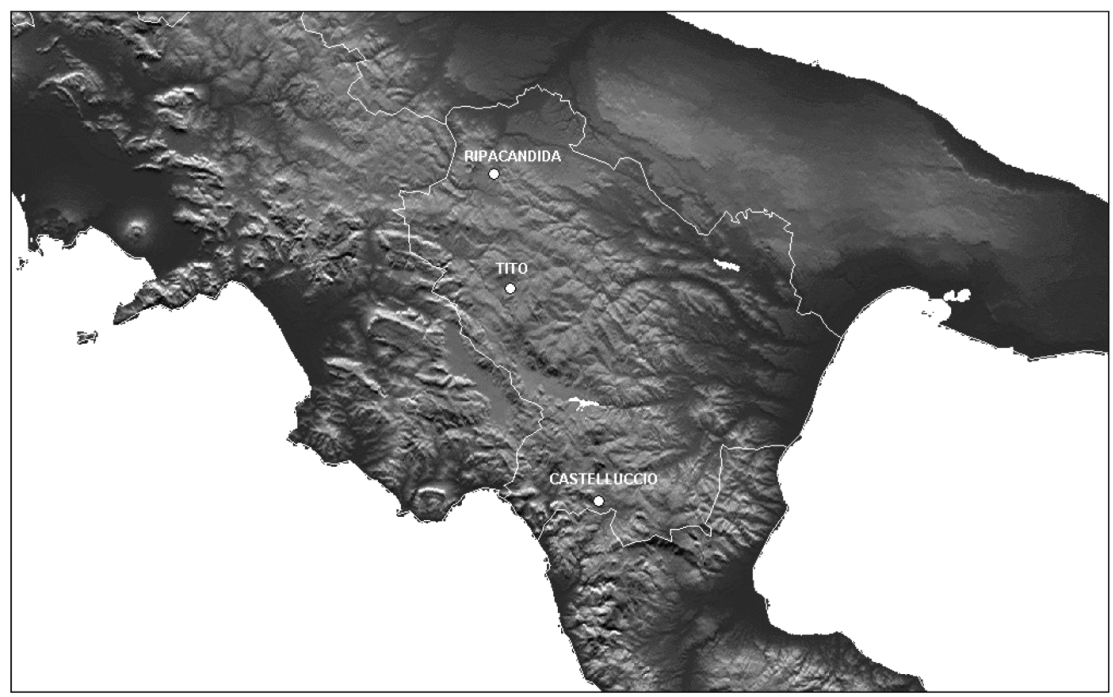

Fig. 2. Map of Basilicata region with location of Tito, Ripacandida and Castelluccio Inferiore areas involved in reactivation slides respectively after meteorological events of February 2005, March 2006 and October 2006. 
families evacuation decrees were issued in order to allow damage valuation. The complexity of the phenomena and the need to obtain information quickly demanded the application of a non-invasive and fast field acquisition method.

Many examples of the Electrical Resistivity Tomography (ERT) method, applied for investigating landslides, are reported in the literature. In many cases the results of its application al- lowed to reconstruct the geometry of landslide body, to outline the sliding surface and to locate areas characterized by high water content (Demoulin et al., 2003; Bichler et al., 2004; Perrone et al., 2004; Lapenna et al., 2005; Meric et al., 2005; Godio et al., 2006).

Taking into account these considerations, by using the Mobile Laboratory for chemicalphysical and geophysical measurements of the

\section{GEOLOGICAL MAP OF TITO AREA}

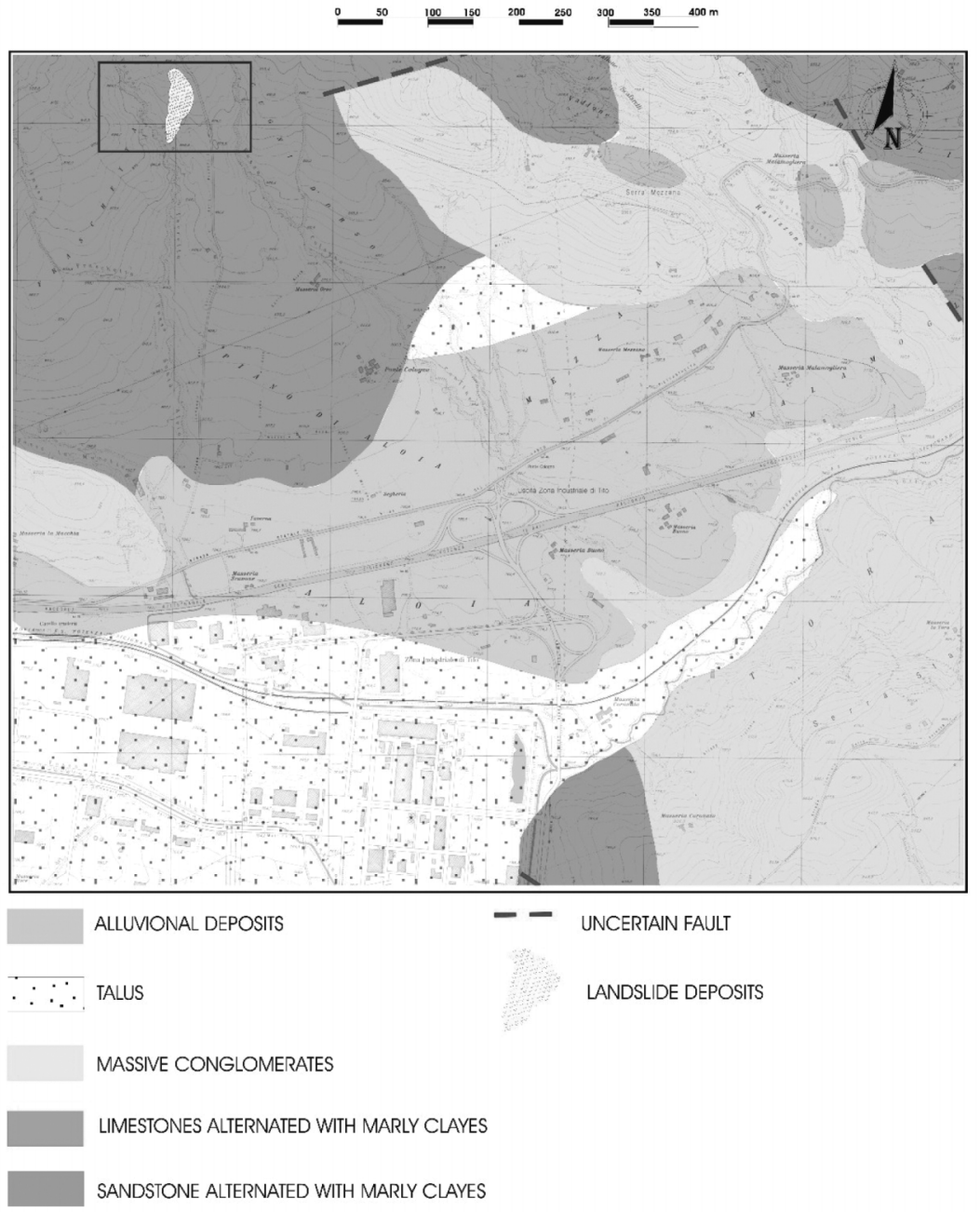

Fig. 3. Geological-geomorphological map of Tito area (Frascheto district) close to the town of Potenza (central part of Basilicata Region). 
Institute of Methodologies for Environmental Analysis (IMAA) of CNR, some ERTs have been performed in the more damaged areas of the Basilicata region. In particular, three sites have been highlighted by the RDICP (fig. 2). The Tito landslide, located at the western side of Potenza town, occurred in February 2005 after a strong snowy precipitation period. The Ripacandida landslide, located in the northern part of the Basilicata region, occurred in March 2006 after a strong rainy precipitation. The Castelluccio Inferiore landslide, located in the Pollino area at the southern part of the Basilicata region, occurred for the first time in November 2005 but it reactivated after a strong rainy event in October 2006.

The areas have been previously studied and the landslide bodies have been mapped by the technical staff of the RDICP. For each site, a geological and geomorphological map was drawn and used to locate the geoelectrical measurements.

For all the sites the results obtained helped the decisions of end users. In particular, the information from the ERTs were very useful in the phases of the valuation damage and slope stabilization planning.

\section{Geological setting}

\subsection{Regional}

The investigated areas are located in Basilicata Region, along the axial zone of the southern Apennine Chain. The latter is mainly composed of sedimentary cover of platform and deep water environments, scraped off from the former Mesozoic Ligurian ocean, the western passive margin of the Adriatic plate and from the Neogene-Pleistocene foredeep deposits of the active margin. From west to east, the main Mesozoic domains are as follows: 1) the internal oceanic to transitional Liguride-Sicilide basinal domains (internal nappes), 2) the Apennine carbonate platform, 3) the LagonegroMolise basins, and 4) the Apulian carbonate platform (Scrocca et al., 2005).

The northern part of the Basilicata Region is characterised by Mount Vulture Volcano, locat- ed along the external thrust belt of the chain. It is a complex strato-volcano whose pyroclastic products are the results of both explosive and effusive activity occurring from the Middle Pleistocene to the Upper Pleistocene (Serri et al., 2001). The southern part of the region is characterized by the Pollino Ridge, formed by Meso-Cenozoic rocks, that marks the boundary between Basilicata and Calabria region (Schiattarella, 1998).

\subsection{Test-sites}

Tito area (fig. 3) is characterized by Sicilide Units, in particular the Corleto Perticara Formation (Fm). From a lithological point of view Corleto Perticara Fm is represented by alternating calcarenites, calcirudites and marly limestones.

According to Pescatore (1988), the terrains attributed to the Sicilide Units (Argille Varicolori, Corleto Perticara and Tufiti di Tusa) could represent the Upper Cretaceous-Neogene portion of the Lagonegro Basin Unit that deposited in the axial part of the basin.

Ripacandida area (fig. 4) is characterised by Meso-Cenozoic substratum Unit of Vulture volcano. In particular, the lithology is represented by pale yellow stratified sandstones, gray siltites, and gravely silty clays with inter-layered grayey calcarenites (Serrapalazzo FormationUpper Burdigalian-Serravallian). The Serrapalazzo Fm is considered the distal portion of the foredeep deposits in the Upper Tortonian.

Castelluccio area (fig. 5) is characterised by un-metamorphosed terrains of the Liguride Units (Paleogene-Jurassic) and overlying Miocene deposits. In fact the terrains belonging to the Liguride Units can be divided into two main groups: metamorphosed and un-metamorphosed terrains. The un-metamorphosed terrains, located in the investigated area, can be considered a «broken formation» related to subduction-accretion processes. It consists of an un-metamorphosed succession containing tectonically embedded blocks. Included within a pelitic-calcareous-arenaceous succession, several lithotypes can be recognised such as ophiolytic suites with their pelagic sedimentary, terrigenous sediments 


\section{GEOLOGICAL MAP OF RIPACANDIDA AREA}

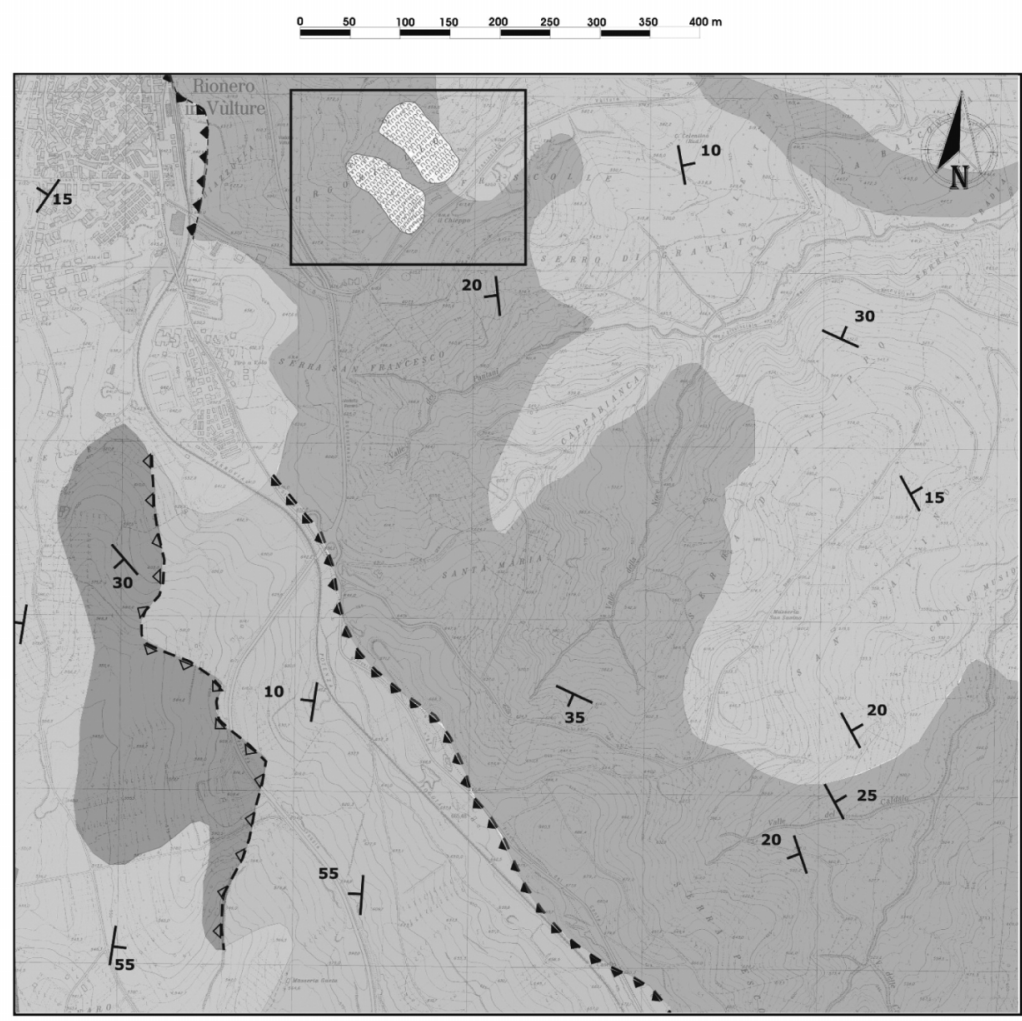

Rionero Subsynthem

The lowermost portion of the sequence is pale yellow in color, made up of massive dm-thick beds of fine grained ashes (fall deposits), plus horizons of accretionary lapilli, and $m$-thick beds of fine grained cross bedded ashes with lenses of $\mathrm{cm}$-size white pumices (pyroclastic surge). Some paleosols are intercalated within this sequence, whose maximum thickness reaches $15 \mathrm{~m}$. The uppermost portion of the stratigraphic sequence is made up of layers of lapilli fallout, sometime whithish at the base and dark gray at the top alternate with dm-size massive layers of yellowish ashes with sparse clasts and pyroclastic surge. Erosive surfaces and thin paleosols are locally present at different stratigraphic position. The medium thickness of this sequence is close to $10-15 \mathrm{~m}$. The massive proximal fall and surge deposits of the $\mathrm{S}$. Andrea center, with $\mathrm{m}$-size ballistic lava blocks, are present at the top of complete sequence. Their thickness is about 14m. An exotic aeolian level made up of fragments of white glas and cristals is present in the middle of the complete sequence.

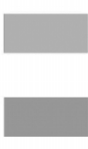

Serra Palazzo Formation

Pale yellow stratified sandstones, gray silties, and grayey silty clays with interlayered grayey calcarenites with wave-ripple laminations and interloyers of colcareous marls (pelagic and torbiditic deposits). UPPER BURDIGALIAN - SERRAVALLIAN.

Numidian Sandstone

Coarse, massive, yellowish quartz-arenites (thick-beds up to $9 \mathrm{~m}$; thin-beds of $30-80 \mathrm{~cm}$ ) with decimetric interlayers of clayey marls (torbiditic deposits). Total thickness up to 300 m. BURDIGALIAN-LANGHIAN?

Pescopagano Formation

Marly clayes, grey, brown, and red, laminated, with intercalation of massive and graded calcarenites; bed thickness $10-50 \mathrm{~cm}$ (pelagic and torbiditic deposits). CRETACIC-OUIGOCENE

Active Landslide deposits

_ $\Delta \Delta \Delta$ - Trust idashed when uncertain; dash and dot when coverad

$-\Delta \Delta \Delta \Delta \ldots$ Reverse Fault (dashed when uncertain; dash and dot when coverad)

Y Strike and dip of beds

Fig. 4. Geological-geomorphological map of Ripacandida area (Frascolla district) close to the Vulture volcano (northern part of Basilicata Region) (from Giannandrea et al., 2004). 


\section{GEOLOGICAL MAP OF CASTELLUCCIO INF. AREA}
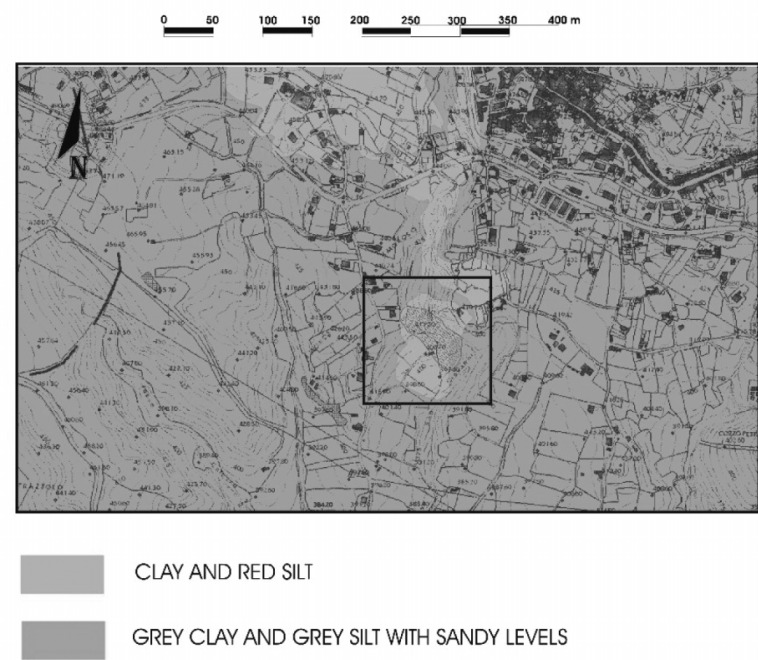

LANDSLIDE DEPOSITS

Fig. 5. Geological-geomorphological map of Castelluccio Inferiore (Amoroso district) close to Pollino area (southern part of Basilicata Region).

(Crete Nere Fm), cherty limestone and colcaniclastic turbidites containing andesitic detritus.

\section{2D Electrical Resistivity Tomography}

Electrical resistivity tomography (ERT) is a geoelectrical method widely applied to obtain $2 \mathrm{D}$ and $3 \mathrm{D}$ high-resolution images of the resistivity subsurface patterns in areas of complex geology (Griffiths and Baker 1993). During the field survey, ERT can be carried out by using different electrode configurations (dipole-dipole, Wenner, Schulumberger, etc.) placed at the surface to send the electric currents into the ground and to measure the generated voltage signals. Technically, during an electrical resistivity measurement, the electric current is injected into the ground via two electrodes and the potential drop is measured between two other electrodes in line with current electrodes (Sharma, 1997). In surveying, several electrical profiles are made with various value of unit electrode spacing. The values of the apparent resistivity for each profile are assigned at a definite depth and position.

In a second step, it is necessary to transform the apparent resistivity values obtained during the field survey into real resistivities of the subsoil. The same processes are needed for depth values.

In this work, the algorithm proposed by Loke and Barker (1996) for the automatic 2D inversion of apparent resistivity data was used. The inversion routine is based on the smoothness constrained least-squares inversion (Sasaki, 1992) implemented by a quasi-Newton optimisation technique.

The subsurface is divided into rectangular blocks, whose number corresponds to the number of measurement points. The optimisation method adjusts the $2 \mathrm{D}$ resistivity model trying to reduce iteratively the difference between the calculated and measured apparent resistivity values. The Root-Mean-Squared (RMS) error gives a measure of this difference. 

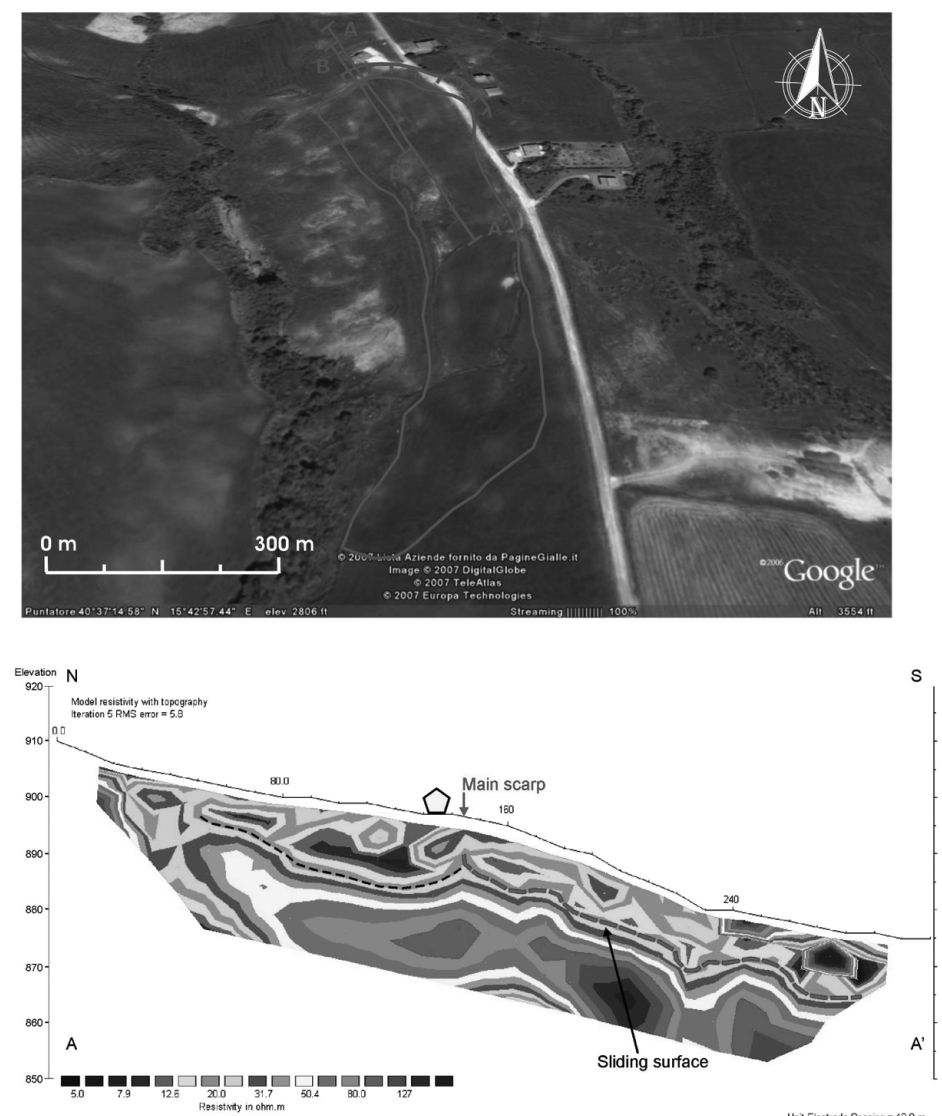

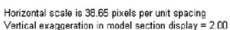

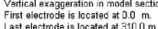

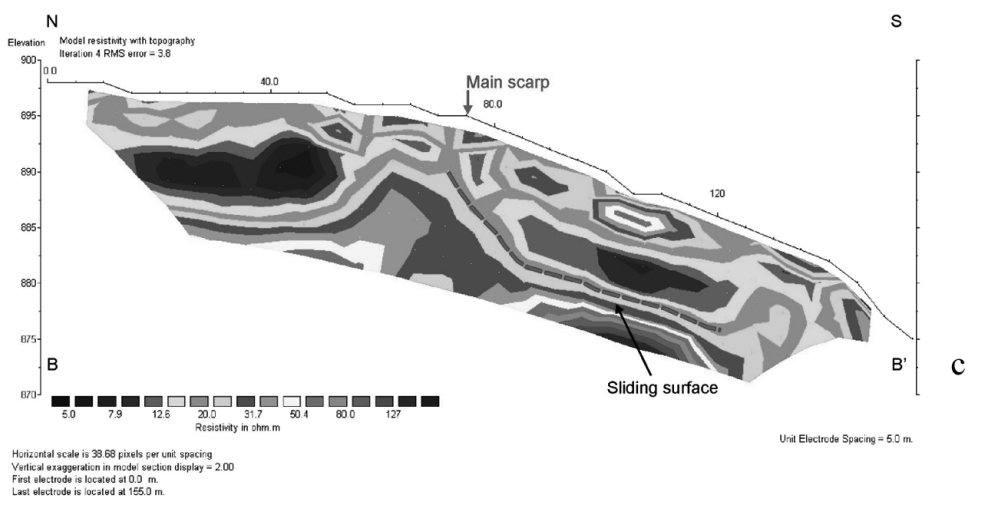

Fig. 6a-c. a) Traces of the electrical resistivity tomographies (red lines) on Tito (Frascheto district) landslide; b) $2 \mathrm{D}$ Electrical resistivity tomography (10 m electrode spacing) carried out with direction parallel to the longitudinal axis of the landslide; c) 2D Electrical resistivity tomography (5 m electrode spacing) carried out with direction parallel to the longitudinal axis of the landslide. 


\section{Results of 2D-ERT and Discussion}

A knowledge of local geology, associated with the high spatial resolution of the measumements, gave us an interpretative tool to explain the ERTs obtained for each case study of this work.

All the tomographies show a resistivity contrast between shallow conductive and deeper resistive material. The conductive material was associated with slide material which is reshuffled and rich in water. The sliding surfaces were located in a zone where the resistivity values clearly change. Then, the dashed lines reported on each tomographies represent the higher probability sliding surface.

\subsection{Tito landslide}

Two ERTs along the same profile were carried out in a direction parallel to the longitudinal axis of the Tito landslide (fig. 6a) using a multielectrode system with 32 electrodes and the dipole-dipole array. The first one ( $\left.\mathrm{AA}^{\prime}\right)$ was carried out using an electrode spacing of $10 \mathrm{~m}$ and it reached an investigation depth of about 20-25 m (fig. 6b). The second one (BB') was performed using an electrode spacing of $5 \mathrm{~m}$ reaching an investigation depth of about $15 \mathrm{~m}$ (fig. 6c). Both the tomographies were topographically corrected. The AA' ERT shows a shallow (10-15 m thick) conductive layer, with electrical resistivity $(\rho)$ values less than $20 \Omega \mathrm{m}$, which covers a more resistive material $(\rho>40$ $\Omega \mathrm{m})$. The conductive layer could be associated with slide material, the resistive zone with the bedrock not involved in the movement. The highest conductive nucleus $(\rho<10 \Omega \mathrm{m})$ located before the source area of the landslide, at a distance ranging from 90 to $140 \mathrm{~m}$ from the profile origin, could be associated with an area characterized by high water content. The same resistivity distribution characterized the BB' $^{\prime}$ ERT. The higher shallow spatial resolution of the ERT allows a better geometrical definition of the shallow conductive layer, which is associated with slide material. Moreover, the conductive nucleus located before the source area appears more visible. Taking into account that an increase in the water content could cause an increase in the pore pressures then a weakening of the slope, the presence of this high conductive nucleus could be one of the causes of the movement.

\subsection{Ripacandida landslide}

A tomography with direction parallel to the longitudinal axis of the landslide was carried out on the Ripacandida landslide (fig. 7a) using a multielectrode system with 32 electrodes $5 \mathrm{~m}$ spacing and a dipole-dipole array. The central part of the AA' ERT (fig. 7b), with topographical correction, shows a weak resistivity contrast between a relatively high-resistivity zone $(\rho>$ 60-100 $\Omega$ ) and a relatively low-resistivity zone $(\rho<15-20 \Omega)$ at a depth of about $12-13 \mathrm{~m}$. The low-resistivity zone has a lenticular shape which is likely to be associated with a high clayey content and high saturation levels in the landslide. The deep relatively high-resistivity zone is considered to reflect the bedrock which is not involved in the landslide. The shallow high-resistivity nuclei may be associated with intercalations within the disturbed material. It is worth noting that the low-resistivity zone is limited on both sides of the landslide.

\subsection{Castelluccio landslide}

Two ERTs were carried out on the Castelluccio landslide (fig. 8a) using a multielectrode system with 32 electrodes $5 \mathrm{~m}$ spacing and a Wenner-Schlumberger array. Both the ERTs were topographically corrected. The first $\left(\mathrm{AA}^{\prime}\right)$ was performed with parallel direction to the longitudinal axis (fig. 8b) of the landslide, the second one $\left(\mathrm{BB}^{\prime}\right)$ with a transversal direction (fig. 8c).

The first part of the $\mathrm{AA}^{\prime}$ longitudinal ERT shows conductive material, whereas higher resistive material characterizes the second part. The resistivity distribution suggests that the top of the slope is characterized by high water content. This hypothesis was confirmed by the in-field observations since during the measurements the ground water table appeared on the surface. 
The same tomography shows a very high resistive nucleus located at a distance of about $60 \mathrm{~m}$ from the origin. Taking into account the position and the resistivity values the nucleus could be associated with the gabionades which have been built to increase the stability of the slope. The ERT shows that the depth of the gabionades did not reach the sliding sur-
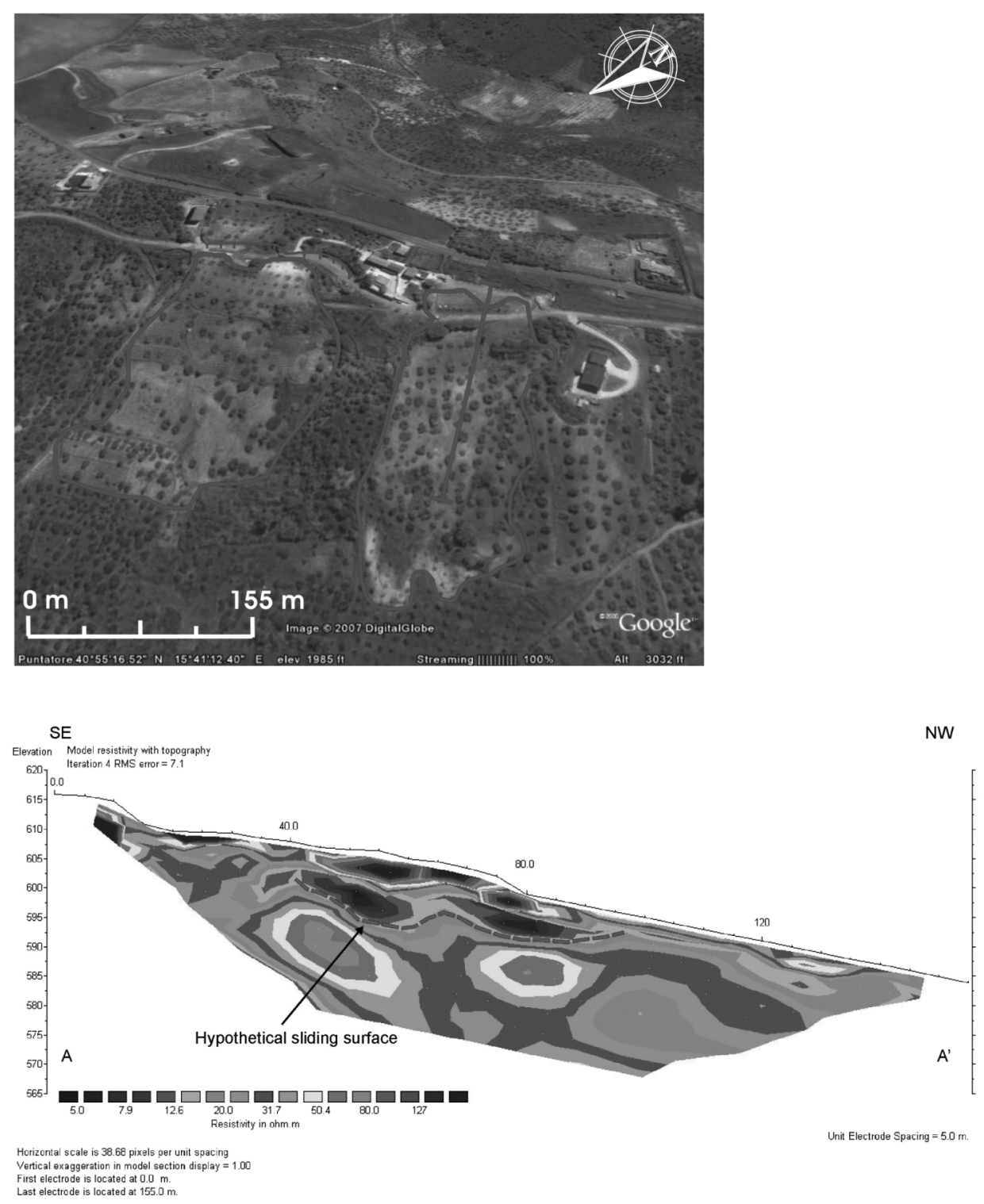

Fig. 7a,b. a) Traces of the electrical resistivity tomographies (red lines) on Ripacandida (Frascolla district) landslide; b) 2D Electrical resistivity tomography carried out with direction parallel to the longitudinal axis of the landslide. 

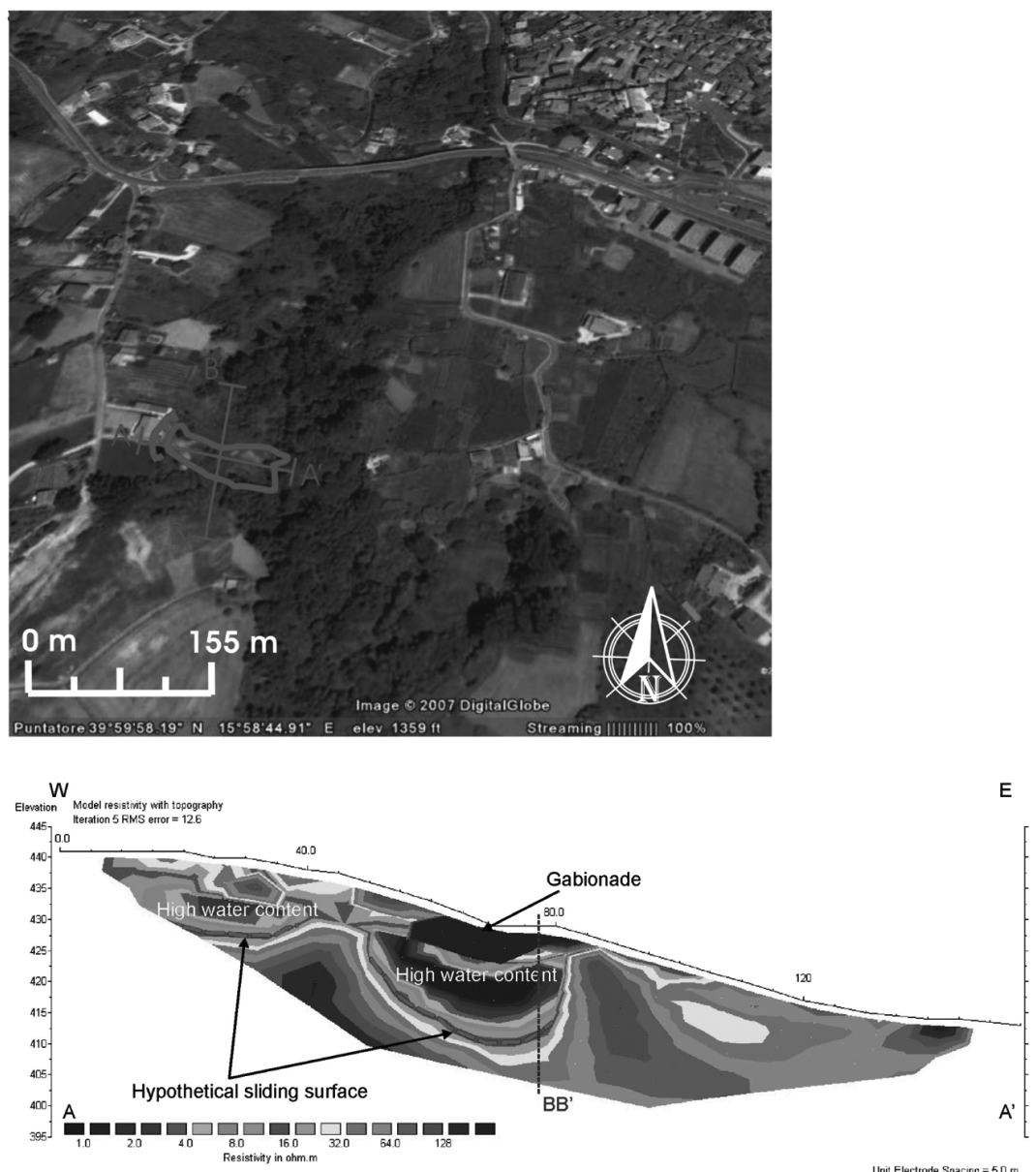

Horizental scale is 38.68 pixels per unt spacing Vertical exaggeration in model section
First electrode is locat tec $510.0 \mathrm{~m}$.
Last electrode is loc ated at $155.0 \mathrm{~m}$

S

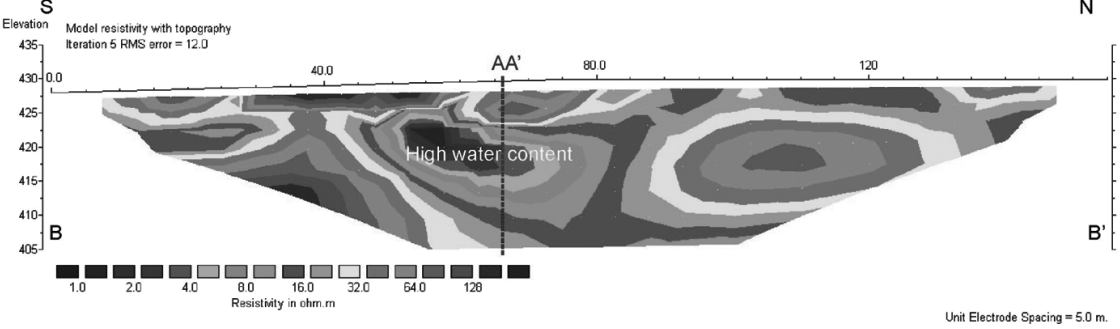

Horizontal scale is 38.68 pixels per unit spacing

Vertical exaggeration in model section display $=1.00$

First electrode is located at $0.0 \mathrm{~m}$.

Fig. 8a,b. a) Traces of the electrical resistivity tomographies (red lines) on Castelluccio Inferiore (Amoroso district) landslide; b) 2D electrical resistivity tomography performed with direction parallel to the longitudinal axis of the landslide; c) 2D electrical resistivity tomography carried out with direction transversal to the landslide body. 
face; it is possible that during the intervention phase wrong sizes of the landslide were considered.

The $\mathrm{BB}^{\prime}$ transversal ERT shows a chaotic distribution of the resistivity values yielding more information on the geometry of the investigated body. In the central part of the tomography is again present a conductive nucleus which is associated with high water content material. The high resistive nuclei could be related to compact material embedded in clayey matrix.

\section{Conclusions}

Three landslides, which occurred in Basilicata region after the meteorological events of the 2005 year have been investigated using a geoelectrical technique. In particular, the electrical resistivity tomography method was applied to obtain information on the deep characteristics of the landslide bodies such as sliding surface location, thickness of the slide material, etc. The ERTs also highlighted areas characterized by high water content; the increase in the saturation degree and pore pressures in these areas could have caused a weakening of the slopes.

For each test site, the results obtained proved to be very useful to the RDICP to improve the knowledge of the investigated phenomenon and to plan possible management activities.

In particular, the information obtained in Tito test-site helped to estimate the costs for a future consolidation planning. The results in Ripacandida test-site and, in particular, the location of the sliding surface allowed adequate strengthening structures to be planned for the slope; the area was completely improved. The results in Castelluccio Inferiore highlighted that the uncertainty in the landslide body sizes definition could cause an underestimation or overestimation of the adequate strengthening structures during the intervention planned phase.

Taking into account the cycle of landslides emergency, the information obtained by the application of the ERT method could give a valid contribution during the post-event phase which mainly regards damage evaluation.

\section{REFERENCES}

Bichler, A., P. Bobrowsky, P. Best, M. Douma, J. Hunter, T. CALvert and R. Burns (2004): Three-dimensional mapping of a landslide using a multi-geophysical approach: the Quesnel Forks landslide, Landslide, 1, 29-40.

Demoulin, A., A. Pissart and C. Schroeder (2003): On the origin of late Quaternary paleolandslides in the Liege (E Belgium) area, Int. J. Earth Sci., 92, 795-805.

Giannandrea, P., L. La Volpe, C. Principe and M. SchiatTARElla (2004): Carta Geologica del Monte Vulture, scala 1:25:000 (Lac Litografia artistica cartografica, Firenze).

Godio, A., C. Strobbia and G. De Bacco (2006): Geophysical characterisation of a rockslide in an alpine region, Eng. Geol., 83, 273-286.

GRIFFITHS, D.H. and R.D. BAKER (1993): Two-dimensional resistivity imaging and modelling in areas of complex geology, J. Appl. Geophys., 29, 211-226.

Lapenna, V., P. Lorenzo, A. Perrone, S. Piscitelli, E. RIZZO and F. SDAO (2005): Case history: 2D electrical resistivity imaging of some complex landslides in $\mathrm{Lu}-$ canian Apennine (Southern Italy), Geophysics, 70 (3), B11-B18.

LOKE, M.H and R.D. BAKER (1996): Rapid least-squares inversion of apparent resistivity pseudosections by quasi-Newton method, Geophys. Prospect., 44, 131-152.

Meric, O., S. Garambois, D. Jongmans, M. Wathelet, J.L. Chatelain and J.M. VengeOn (2005): Application of geophysical methods for the investigation of the large gravitational mass movement of Sechilienne, France, Can. Geotech. J., 42, 1105-1115.

Perrone, A., A. Iannuzzi, V. Lapenna, P. Lorenzo, S. Piscitelli, E. Rizzo and F. SDAO (2004): High-resolution electrical imaging of the Varco d'Izzo earthflow (Southern Italy), J. Appl. Geophys., 56 (1), 17-29.

Pescatore, T. (1988): La sedimentazione miocenica nell'Appennino campano-lucano, Mem. Soc. Geol. It., 41, 37-46.

SASAKI, Y. (1992): Resolution of resistivity tomography inferred from numerical simulation, Geophys. Prospect., 54, 453-464.

Schiattarella, M. (1998): Quaternary tectonics of the Pollino Ridge, Calabria-Lucania boundary, Sourthern Italy, Geol. Soc. London Spec. Pubbl. 135, 341-354.

Scrocca, D., E. Carminati and C. Doglioni (2005): Deep structure of the Southern Apennine (Italy): thin skinned or thick-skinned?, Tectonics, 24, TC3005, doi: 10.1029/ 2004TC001634

SELLI, R. (1962): Il Paleogene nel quadro della geologia dell'Italia meridionale, Mem. Soc. It., 3, 735-789.

SERri, G., F. InNOCEnTI and P. MANetTi (2001): Magmatism from Mesozoic to Present: petrogenesis, timespace distribution and geodynamic implications, in Anatomy of an Orogen: the Apennines and Adjacent Mediterranean Basins, edited by G.B. VAI and I.P. MARTINI (K1 Acad. Publ., Dordrecht, The Netherlands), 77-103.

Sharma, P.S. (1997): Enviromental and Engineering Geophysics (Cambridge University Press).

WWw.SINANET.APAT.IT (2005): Gli Indicatori del Clima in Italia nel 2005, I Anno, APAT. 